\title{
Optimization of the soldering process by the DMAIC methodology
}

\author{
Michal Zasadzień \\ Institute of Production Engineering, Silesian University of Technology, Roosevelta 26, 41-800 Zabrze, Poland, +48(32)2777350, e-mail: \\ michal.zasadzien@polsl.pl
}

\begin{abstract}
The chapter presents the use of the DMAIC method for the analysis and improvement of the process of soldering pins in a plug connecting a bundle of wires to the board of a controller; a part of the steering system of a car. The main problem in the soldering process, that is an unsatisfactory share of bad soldered connections between the board and the plug and the instability of that number, was identified by means of a five-phase improvement process. Key points and main causes of the defect were pointed out, and process improvement measures were suggested. Due to the analysis conducted and the correct implementation of improvement measures the share of defective connections has been decreased twofold.
\end{abstract}

Key words - improvement, process, soldering, six sigma, production, quality

\section{Introduction}

Striving to constantly improve and streamline a production process, a modern quality engineer has many methods of quality management at their disposal (TAGUE N.R., 2004. SKOTNICKA-ZASADZIEŃ B., GLENC D., 2006. KRYNKE M., MiELCZAREK K., 2013). Apart from these, many other less complicated tools are used, such as the Pareto diagram, the Ishikawa diagram or the 5 WHYs (MIDOR K., 2014. SYGUT P., 2014). One of the elements of streamlining a production process can be the DMAIC (Define - Measure Analyze - Improve - Control) method, which originated in the automotive industry and is successfully used in improving processes in accordance with the assumptions of Six Sigma (GOŁĘBIOWSKI M., 2010. KRZEMIEŃ E., Wolniak R., 2007. WoJTASZAK M., BIALY W., 2013).
The improvement cycle using the DMAIC method consists of the following elements:

- Define. During this stage, a team of people who are going to be responsible for defining clients of a given production process, their needs and requirements.

- Measure. The team is tasked with creating a map of the process which requires improvement. Main measures of effectiveness and efficiency should be defined at this point in order to use the concept of Six Sigma.

- Analyse. During this stage, by analysing the individual parameters of the process, the team will be able to determine the causes of the problem, which will then have to be eliminated or fixed.

- Improve. The penultimate stage of the improvement method, during which all the measures introduced are summed up. 
- Control. After applying corrective measures comes a control of the improvements introduced (ECKES G., 2000).

It is worth noticing here that the cycle of introducing the DMAIC method is completely compatible with the concept of constant improvement proposed by $\mathrm{E}$. Deming (DEMING W.E., 2000) required by the ISO 9001 series standards and continuously developed (JAGUSIAK-KOCIK M., 2014). Figure 1 shows a comparison of both concepts.



Fig. 1 PDCA vs DMAIC

Source: Sokovic M., Pavletic D., Kern PiPan K., 2010

During the implementation of the DMAIC method, a number of supplementary methods and techniques is used in the form of quality improvement tools and methods.

\section{Example problem solution}

\subsection{Defining the problem}

The first stage of the DMAIC methodology is problem identification. In the case of the analysed example, it is the presence of defects in the soldered connection between the plug of a bundle of wires and the printed circuit board. The problem is not only the number of defective connections, but also the fact that it fluctuates. Over a period of 30 weeks the number fluctuated in the 4000 - 16000 PPM range. The goal of the project was to reduce the number of defective connections to the level of $<3000$ PPM.

In the soldering process there are three effects of bad quality soldered connections which result from the analysis of the defect sheets and constitute a tangible loss to the company. The following types are distinguished:

- loss of cycle due to bad quality of the soldered connections which requires correction by the operator at the last visual control station,

- loss of cycle due to solder alloy (tin) breaking off from the spool during the soldering process,
- scrapping of damaged parts (Wire Harness and Controller Board plugs).

Having analysed all the elements of the process which could influence the high defect indicator and the variability of the soldering process, the following factors have been singled out:

- a lack of systematic technical inspections of the machines by the maintenance department,

- a lack of inspections of the technical condition of the pallets and their masks for the proper alignment of the plug, printed circuit board and wires in the soldering machine,

- unstable process of dispensing the flux onto the soldered area on the circuit board,

- inefficient pin and wires pre-heating process.

\subsection{Measurements}

At this stage of the DMAIC method, an SIPOC diagram which shows the key elements of the production process was drawn up. SIPOC is a tool which makes it possible to map every step of a given process. The abbreviation comes from the words Suppliers, Inputs, Process, Outputs and Customers, and consists of the following elements:

- a supplier - a person (or group of persons) who supplies key information and input materials for the process,

- inputs - materials, information input into the process along with the requirements,

- a process - a set of activities which transforms input elements into output elements,

- outputs - materials, information which exits the process,

- a customer - a person, a group of people, or a process which receives the final product, and their requirements for the products (NOWAKOWSKA M., 2012).

Following that, all the operations required in the soldering process as well as machines taking part in individual operations were identified and described. Similarly, all the important process parameters and the order of conducting individual operations and procedures were also described (e.g. the amount of flux used, the position of the solder pin, pre-heating temperature of the soldered elements, the soldering order of individual pins, the solder alloy feeding rate, the position of pallets and masks). Based on these pieces 
of information, a map of the process showing all the phases of the process along with their key inputs and outputs was created in a graphic form.

\subsection{Analysis}

At this stage of the project all the data on factors which could cause defects in the soldering process were analysed. In order to find out how much of an impact the effects of defects in the soldering process have, a PFMEA (TAGUE N.R., 2004) was conducted for all the elements of the soldering process, i.e.:

- subassembly of the plug to the case,

- application of flux onto the soldering area,

- positioning the soldering head,

- the actual soldering process.

By means of the PFMEA, elements of the process with the highest WPR indicator value were identified and the ones which constitute a threat to the soldering process (WPR of at least 160) were recognized. Table 1 presents the most significant potential causes of defective soldered connections. In total, 30 potential defect causes were analysed.

Table 1. PFMEA results

\begin{tabular}{|c|l|c|}
\hline NO. & \multicolumn{1}{|c|}{ POTENTIAL CAUSES OF DEFECTS } & RPN \\
\hline 1 & Lack of skill on the operator's end & 240 \\
\hline 2 & $\begin{array}{l}\text { Incorrect position of the tool which positions the } \\
\text { CCA board }\end{array}$ & 160 \\
\hline 3 & Incorrect position of the robot's head & 192 \\
\hline 4 & Needle contamination & 192 \\
\hline 5 & Incorrect pre-wetting of the soldering pin & 240 \\
\hline 6 & Soldering pin in bad technical condition & 240 \\
\hline 7 & Oxidised binding material & 168 \\
\hline
\end{tabular}

\subsection{Improvement}

Based on the PFMEA results, the following measures were introduced to prevent the occurrence of defects:

- the operators were given training on examining the quality of the soldered connections in accordance with standards;

- a training was conducted on the proper positioning of tools which determine the board's position in the soldering machine (the pallet and the mask);
- new equipment for pre-heating the soldered elements was installed,

- sheets were introduced to control the technical functionality of the positioning tools - if the pallet generates three errors, the operator must inform their supervisor to remove it from the process;

- a procedure for cleaning soldering pins was introduced, taking place every day during the $1 \mathrm{st}$ shift, and potential replacement, should their technical condition warrant it;

- the soldering robots were equipped with counters which count the number of cycles performed by the soldering pin (one soldering point counts as one cycle performed by the robot);

- the amount of flux dispensed was set by regulating the opening time of the nozzle, the feeding pressure and the air pressure;

- the soldering alloy was changed from oxidised to unoxidised tin and it was wound properly onto the spool;

- instructions for changing sponges used for cleaning the soldering pin of deposits and tin once per shift was placed at the soldering station;

- cleaning the filter element in the fume exhaust system once per week.

\subsection{Control}

With the improvement stage finished, the project's primary focus shifted to constant monitoring of the measures implemented in order to maintain a sufficiently high level of the products quality.

In order to verify the effectiveness of the corrective measures taken, another FMEA of the soldering process was conducted. The WPR indicator of all the defect causes analysed did not exceed 120 .

After introducing the changes to the process, the number of defective elements decreased and reached the target level of < 3000 PPM. The variability in the number of defective connections over the course of a week also decreased; it currently oscillates between 1000 and 2700 PPM.

To ensure the durability of changes implemented into the process, a control plan was devised during the last stage of the analysis, consisting of the following elements: 
- a list of elements in the process which need to be monitored and controlled along with the frequency of measurements,

- a list of streamlining measures and people responsible for implementing and maintaining them,

- a list of standards implemented into the process.

Measurement and monitoring measures created as a result of the analysis conducted using the DMAIC method are presented in Table 2. The list of improvements and people chosen to be responsible for their functioning are presented in Table 3 .

Table 2. Monitoring and control

\begin{tabular}{|l|l|l|}
\hline Control element & Defect indicator & $\begin{array}{l}\text { Scrapped parts } \\
\text { indicator }\end{array}$ \\
\hline Control limit & 3000 PPM & PLN 2 500 \\
\hline Control frequency & $1 /$ day & $1 /$ month \\
\hline $\begin{array}{l}\text { Measurement sys- } \\
\text { tem }\end{array}$ & $\begin{array}{l}\text { defect analysis } \\
\text { sheet }\end{array}$ & $\begin{array}{l}\text { Scrapping } \\
\text { reports }\end{array}$ \\
\hline Result presentation & Chart & Chart \\
\hline Response plan & $\begin{array}{l}\text { Measures taken } \\
\text { at the morning } \\
\text { meeting be- } \\
\text { tween the engi- } \\
\text { neers and the } \\
\text { project leader }\end{array}$ & $\begin{array}{l}\text { Measures } \\
\text { taken at the } \\
\text { monthly } \\
\text { summary } \\
\text { meetings }\end{array}$ \\
\hline Person responsible & $\begin{array}{l}\text { Quality engi- } \\
\text { neer }\end{array}$ & $\begin{array}{l}\text { Quality engi- } \\
\text { neer }\end{array}$ \\
\hline
\end{tabular}

Table 3. Monitoring and control

\begin{tabular}{|l|l|}
\hline \multicolumn{1}{|c|}{ Person responsible } & \multicolumn{1}{c|}{ Measures taken } \\
\hline Technologist & $\begin{array}{l}\text { Correct condition and tem- } \\
\text { perature of the flux }\end{array}$ \\
\hline Technologist & $\begin{array}{l}\text { Correction of the flux feed- } \\
\text { ing settings }\end{array}$ \\
\hline Production engineer & $\begin{array}{l}\text { Counters of cycles per- } \\
\text { formed by the soldering pin }\end{array}$ \\
\hline Production engineer & $\begin{array}{l}\text { Soldering pin replacement } \\
\text { control sheets }\end{array}$ \\
\hline Production engineer & Counter state control sheets \\
\hline Technologist & $\begin{array}{l}\text { Soldering station instruc- } \\
\text { tions - pin cleaning }\end{array}$ \\
\hline Technologist & $\begin{array}{l}\text { Unoxidised soldering alloy } \\
\text { and its correct winding }\end{array}$ \\
\hline Production engineer & $\begin{array}{l}\text { Cleaning sponge replace- } \\
\text { ment, 1/shift }\end{array}$ \\
\hline
\end{tabular}

\begin{tabular}{|l|l|}
\hline Production engineer & $\begin{array}{l}\text { Cleaning the filter element, } \\
1 / \text { week }\end{array}$ \\
\hline Production engineer & $\begin{array}{l}\text { Control sheets of the tools } \\
\text { positioning the boards in the } \\
\text { soldering machine }\end{array}$ \\
\hline
\end{tabular}

In the last stage of creating the control plan, standardisation was incorporated (Table 4) whose goal is to maintain the standards which govern the improvement process.

Table 4. Standardisation

\begin{tabular}{|l|l|}
\hline $\begin{array}{c}\text { Person } \\
\text { responsible }\end{array}$ & \multicolumn{1}{c|}{ Measures taken } \\
\hline Technologist & $\begin{array}{l}\text { Instructions, training and verifying the } \\
\text { technical condition of pallets for per- } \\
\text { sons responsible (operators) }\end{array}$ \\
\hline Technologist & $\begin{array}{l}\text { Instructions and training on the correct } \\
\text { positioning of the soldering pin }\end{array}$ \\
\hline $\begin{array}{l}\text { Maintenance } \\
\text { engineer }\end{array}$ & $\begin{array}{l}\text { Prevention by the maintenance depart- } \\
\text { ment within the soldering line }\end{array}$ \\
\hline $\begin{array}{l}\text { Production } \\
\text { engineer }\end{array}$ & $\begin{array}{l}\text { Instruction and training for the opera- } \\
\text { tors on examining the quality of sol- } \\
\text { dered connections in accordance with } \\
\text { the standard }\end{array}$ \\
\hline
\end{tabular}

\section{Summary}

Based on the case study conducted, we can conclude that:

1. The DMAIC method allows to solve complex problems in the production process, improve it, and leads to tangible savings for the company.

2 . The method requires the engagement of significant company resources, from the quality engineers and technologists to production and maintenance engineers.

3. Conducting the analysis in accordance with the methodology guarantees identification of the primary causes of the problem and minimising them effectively.

4. Successful implementation of the control plan ensures the protection of the production process in the future against disruptions caused by identified errors. 


\section{Literature}

1. Deming W.E. 2000. The New Economics for Industry, Government, Education, Second Edition. The MIT Press.

2. ECKES G. 2000. The Six Sigma Revolution: How General Electric and Others Turned Process into Profits. John Wiley \& Sons.

3. GoŁęBIOWSKI M. 2010. DMAIC i DMADV jako metody doskonalenia jakości. Studia i Prace Wydziału Nauk Ekonomicznych i Zarządzania. Nr 21, pp. 135-141.

4. JAGUSIAK-KOCIK M. 2014. Ensuring continuous improvement processes through standardization in the automotive company. Production Engineering Archives. Vol. 2(1), pp. 12-15.

5. KrynKe M., MielCZAReK K. 2013. An evaluation of realization of the production process in the cement mill. Production Engineering Archives. Vol. 1(1), pp.19-21.

6. KRZemień E., WolniaK R. 2007. Analysis of process of constant improvement of six sigma. In: Current trends in commodity science. Zieliński R. (ed.). The Poznań University of Economics Publishing House, pp. 227-232.

7. MIDOR K. 2014. An analysis of the causes of product defects using quality management tools. Management Systems in Production Engineering. No 4(16), pp. 162-167.

8. NowAKOWSKA M. 2012. Wykorzystanie metodologii Six Sigma - Green Belt na procesie lutowania $\mathrm{w}$ przedsiębiorstwie motoryzacyjnym. M.A. thesis. Silesian University of Technology.

9. SKotnicka-Zasadzień B., GlenC D. 2006. Koncepcja kompleksowego zarządzania jakością (TQM) usług medycznych na przykładzie Górnośląskiego Centrum Medycznego. Zeszyty Naukowe Politechniki Śląskiej, s. Organizacja i Zarządzanie. Z. 39, s. 137-143.

10. SoKovic M., PAVletic D., Kern PiPAN K. 2010. Quality Improvement Methodologies - PDCA Cycle, RADAR Matrix, DMAIC and DFSS. Journal of Achievements in Materials and Manufacturing Engineering. Vol. 43, pp. 476-483.

11. SyGUT P. 2014. Process of quality improvement in the company producing building materials. Production Engineering Archives. Vol. 1(2), pp.1618.

12. TAgue N.R. 2004. The Quality Toolbox. 2 nd edition. ASQ Quality Press 2004.
13. WOJTASZAK M., BIAŁY W. 2013. Measurement system analysis of attribute or continuous data, as a one of the first steps in Lean Six Sigma projects. In: Systems supporting production engineering. Kaźmierczak J. (ed.). PA NOVA, pp. 144-162

\section{Acknowledgements}

The article is the result of the registered work with symbol BK-223/ROZ-3/2015 "The importance of the production engineering in the innovative development of products and services" carried out in the Institute of the Production Engineering, Department of Organization and Management at Silesian University of Technology. 